\title{
STRUKTURA POPYTU GLOBALNEGO A WZROST GOSPODARCZY W KRAJACH EUROPY ŚRODKOWEJ I WSCHODNIEJ
}

\begin{abstract}
Streszczenie
Problemem wielu krajów o gospodarce rynkowej jest zapewnienie odpowiedniej struktury popytu globalnego oraz właściwe dynamizowanie poszczególnych jej składowych w celu osiagania wyższego tempa wzrostu gospodarczego. Dotyczy to również krajów Europy Środkowej i Wschodniej, które po rozpoczęciu transformacji ustrojowo-gospodarczej nie osiagały homogenicznego i wysokiego wzrostu realnego PKB. Wśród przyczyn można wymienić: posiadanie zróżnicownych zasobów własnych, wdrażanie odmiennych reform oraz prowadzenie specyficznej polityki makroekonomicznej.

Celem artykułu jest pokazanie związków między strukturą popytu globalnego a wzrostem gospodarczym w krajach Europy Środkowej i Wschodniej w latach 1995-2013.

Artykuł składa się z części teoretycznej i empirycznej. Na początku zaprezentowano krytyczny przegląd literatury dotyczacy podejmowanej problematyki. W dalszej kolejności przedstawiono aspekty metodyczne. Następnie omówiono tempo wzrostu gospodarczego w krajach Europy Środkowej i Wschodniej w latach 1995-2013. W części empirycznej przeanalizowano związki między strukturą popytu globalnego a wzrostem gospodarczym w krajach Europy Środkowej i Wschodniej. W podsumowaniu przedstawiono konkluzje $z$ weryfikacji postawionej hipotezy badawczej oraz sformułowano końcowe wnioski z analizy przeprowadzonej w artykule.
\end{abstract}

Słowa kluczowe: popyt globalny, wzrost gospodarczy, Europa Środkowa i Wschodnia (ESW)

\section{STRUCTURE OF GLOBAL DEMAND AND ECONOMIC GROWTH IN CENTRAL AND EASTERN EUROPEAN COUNTRIES}

\begin{abstract}
Summary
The aim of the paper is to show the contribution of the structure of global demand on the economic growth in the countries of Central and Eastern Europe. The author focuses on the changes of the structure of global demand in the analysed countries in 1995-2013.

The paper consists of a theoretical and an empirical part. The former presents a critical review of the relevant literature. Next, the methodological aspects are discussed. The following section analyses the associations between the structure of the global demand and the economic growth of the Central and
\end{abstract}

\footnotetext{
${ }^{1}$ Prof. nadzw. UEK dr hab. Robert Wojciech Włodarczyk - Wydział Ekonomii i Stosunków Międzynarodowych, Uniwersytet Ekonomiczny w Krakowie; e-mail: ror20@wp.pl.
} 
Eastern European countries during the transformation process. The final part includes the author's conclusions concerning the verification of the research hypothesis and the analysis of the results from the conducted studies.

Key words: global demand, economic growth, Central and Eastern Europe (CEE)

\section{Wstęp}

Zmiany ustrojowo-gospodarcze w krajach Europy Środkowej i Wschodniej zmuszają do przeprowadzania oceny różnych zjawisk makroekonomicznych, w tym identyfikacji najważniejszych czynników, które decydują o ich nasileniu i ewolucji. Znajomość wielu związków przyczynowo-skutkowych może być pomocna w przeprowadzaniu podobnych procesów w innych regionach świata, ale także może służyć kreowaniu własnej polityki makroekonomicznej i strategii rozwoju gospodarczego na kolejne lata. Transformacja ustrojowo-gospodarcza wyzwoliła przemiany w obszarze: instytucjonalnym, strukturalnym i społeczno-gospodarczym. Procesy te w różny sposób wpłynęły na wiele kategorii mikro- i makroekonomicznych, natomiast obecnie stanowią przedmiot pogłębionych analiz naukowych. Szczególne miejsce w procesie przemian dokonujących się w krajach Europy Środkowej i Wschodniej zajmuja przeobrażenia strukturalne i ich konsekwencje dla gospodarki.

Od początku transformacji ustrojowej wzrost gospodarczy w krajach Europy Środkowej i Wschodniej charakteryzował się względnie dużą zmiennościa. Kraje te, posiadając odmienne zasoby wyjściowe, prowadząc specyficzna politykę makroekonomiczną oraz wdrażając wiele reform, przeszły przez różne ścieżki wzrostu realnego PKB. Generalnym celem rządów krajów Europy Srodkowej i Wschodniej było takie wdrażanie reform gospodarczych, aby nie zakłócać istniejącego wzrostu, a dodatkowo tworzyć warunki do jego stymulowania. Wiele krajów doświadczyło nader szybkiego tempa wzrostu, które było zarazem wyraźnie wyższe niż to występujące w rozwiniętych krajach Europy Zachodniej. W czasie dotychczasowych przemian wystapiły także okresy znacznie spowolnionego tempa wzrostu realnego PKB, czego negatywnym skutkiem było wyhamowanie procesu doganiania krajów rozwiniętych. Wynikało to przede wszystkim ze źle prowadzonej polityki makroekonomicznej oraz nieodpowiednio wdrażanych reform gospodarczych. Duży wpływ miały również początkowe różnice w poziomie rozwoju rozpatrywanych gospodarek, zwłaszcza pod względem strukturalnym i instytucjonalnym.

Jedna z ważniejszych kwestii zarówno w teorii ekonomii, jak i w praktyce jest poszukiwanie kanałów oraz siły oddziaływania między przemianami strukturalnymi a wzrostem gospodarczym. Ważny jest w równej mierze ogólny kształt danej struktury, jak i identyfikacja, który z elementów składowych rozpatrywanej struktury i w jakim stopniu może decydować o dynamice wzrostu gospodarczego.

Problemem badawczym artykułu jest ocena wpływu zróżnicowania struktury popytu globalnego na tempo wzrostu gospodarczego. Zasadniczym celem artykułu jest przeanalizowanie zmian struktury popytu globalnego i tempa wzrostu gospodarczego w krajach Europy Środkowej i Wschodniej w latach 1995-2013. 
Przyjęty cel artykułu i przywołana literatura pozwoliły postawić następującą hipotezę badawcza: Kraje Europy Środkowej i Wschodniej odznaczają się heterogenicznymi strukturami popytu globalnego względem UE-15, co z kolei znajduje odzwierciedlenie w odmiennych ścieżkach wzrostu gospodarczego.

Artykuł składa się z kilku części. Na początku zaprezentowano krytyczny przegląd literatury, co umożliwiło zdiagnozowanie obecnego stanu wiedzy dotyczącego podejmowanej problematyki. W dalszej kolejności przedstawiono problem badawczy, aspekty metodyczne, a także omówiono procedurę tej analizy z uwzględnieniem przyjętych narzędzi badawczych. Następnie scharakteryzowano tempo wzrostu gospodarczego w krajach Europy Środkowej i Wschodniej w latach 1995-2013. W części empirycznej artykułu przeanalizowano związki między strukturą popytu globalnego a wzrostem gospodarczym w krajach Europy Środkowej i Wschodniej. Artykuł kończy sformułowanie wniosków z przeprowadzonej analizy.

\section{Przegląd literatury}

Ewolucja struktury różnych zjawisk ekonomicznych jest istotnym zagadnieniem zarówno z punktu widzenia teoretycznego, jak i praktycznego. Pozwala to ocenić aplikacyjność różnych teorii [Sosenko, 2008, s. 58] oraz tworzy atrybut do syntetycznej weryfikacji empirycznych zależności gospodarczych w ujęciu czasoprzestrzennym. Rozumienie zasad i mechanizmów determinujących dynamiczne zmiany struktury w poszczególnych krajach jest $\mathrm{z}$ pewnością pomocne również w realizacji celu analitycznego i predyktywnego. Rozwój, który nie przynosi zmian strukturalnych, jest rzadko spotykany [Sadowski, 2005, s. 9]. Dzieje się tak, gdyż dynamika oddziaływania poszczególnych składowych struktur wyzwala efekty zmian w poziomach potencjałów tych składowych, powodując różnicę potencjałów tego oddziaływania, która z kolei tworzy zupełnie nowe zbiory elementów struktur [Broszkiewicz, 2004, s. 17]. Przeobrażenia strukturalne są bowiem nieodłączną cechą rozwoju, stanowiąc zarazem rudymentarny czynnik jego przyspieszenia [Wydymus, 1988, s. 162]. Innymi słowy, rozwój jest pewnego rodzaju ciagiem przemian dokonujących się w strukturze gospodarki [Malina, 2004, s. 20].

Zmiany strukturalne w gospodarce moga mieć charakter zarazem podażowy, jak i popytowy. Znaczna część dyskusji w literaturze przedmiotu dotyczy przemian struktur o charakterze podażowym. Karpiński [Karpiński, 1986] wskazuje, że im głębsze są zmiany struktur, tym szybsze jest tempo rozwoju gospodarczego, a zatem dynamika rozwoju gospodarczego jest funkcja przemian strukturalnych. W badaniach empirycznych potwierdzono pozytywny wpływ przemian strukturalnych na łączną wydajność czynników produkcji [Kaczorowski, Rogut, Tokarski, 2002, s. 35-64]. W długim okresie zasadniczą barierą utrzymywania wysokiego tempa wzrostu gospodarczego jest istniejąca, nieracjonalna struktura gospodarcza z dużym udziałem przemysłu ciężkiego. Szczególnie niekorzystna jest struktura gospodarcza zdominowana przez przemysł wydobywczy i surowcowy o przestarzałej technologii, petryfikująca niski poziom gospodarczy kraju i przestarzałą strukturę handlu zagranicznego. Reforma strukturalna staje się w wielu przy- 
padkach nadrzędnym celem polityki gospodarczej i przemysłowej. Chodzi o restrukturyzację i prywatyzację dużych przedsiębiorstw państwowych i instytucji finansowych. Oprócz prywatyzacji, w niektórych branżach przemysłu ciężkiego (w górnictwie węglowym, przemyśle stalowym, stoczniowym i chemicznym) są wymagane programy redukcji działalności i przesunięcia czynników produkcji do gałęzi nowoczesnych i bardziej wydajnych. Zmiany strukturalne w gospodarce, polegające na technicznej restrukturyzacji przemysłu i rolnictwa, prowadzą także do rozwoju nowoczesnego sektora usług. Może to mieć konsekwencje w wydajności pracy, poziomie dochodów oraz często znajduje odzwierciedlenie w zmianach struktury popytu globalnego.

Ważną część dyskursu na temat zmian strukturalnych w gospodarce stanowia przemiany o charakterze popytowym. Rola popytu globalnego w rozwoju gospodarki została szczególnie wyeksponowana przez J. M. Keynesa [Keynes, 1985]. Liczne rozwinięcia tej problematyki znajdują źródło w pracach opartych na idei keynesizmu, w których analizuje się zakres wpływu popytu globalnego i poszczególnych elementów składowych jego struktury na wzrost gospodarczy. Państwo jako podmiot oddziałujący na procesy w gospodarce, sterując popytem globalnym, musi znać nie tylko jego poziom ogólny, ale także strukturę [Jęruchniewicz, 2011, s. 182]. Najważniejszą składową popytu globalnego jest konsumpcja [Bywalec, 2007], której zmiany w duchu idei keynesowskiej są źródłem wzrostu produkcji finalnej jedynie w granicach dostępnych zdolności wytwórczych gospodarki. Kolejnym elementem struktury wydatków globalnych jest popyt inwestycyjny, którego znaczenie szczególnie uwidacznia się w krótkookresowym rozwoju i wzroście gospodarki [Woźniak, 2004]. Wyjątkowo niebezpieczne jest ograniczenie popytu inwestycyjnego w strukturze popytu globalnego w okresie narastających pesymistycznych oczekiwań co do koniunktury makroekonomicznej. Ograniczenie działalności inwestycyjnej może utrwalić niekorzystne tendencje we wzroście gospodarczym, gdyż odbudowa zaufania przedsiębiorców jest trudna i długa. Utrzymanie wysokiego popytu inwestycyjnego w gospodarce często stanowi niezbędny warunek przeciwdziałania bezrobociu, które jest skutkiem zmian strukturalnych po stronie podażowej i wiąże się z jednoczesnym wdrażaniem programów zagospodarowania wolnej siły roboczej. Realizacja reform strukturalnych niejednokrotnie prowadzi do zmian deficytu budżetowego i sytuacji fiskalnej. Poprawa w zakresie wielkości oszczędności publicznych jest istotna, jeśli chodzi o zapewnienie możliwości finansowania nakładów inwestycyjnych i zabezpieczenie trwałego wzrostu gospodarczego. Badania wskazują, że publiczne wydatki inwestycyjne wpływaja nie tylko na wzrost popytu globalnego, lecz również na wyższą produkcję globalną [Straub, Tchakarov, 2007]. Przemiany strukturalne pozwalają na zwiększenie międzynarodowej konkurencyjności gospodarki i przemysłu, co warunkuje zwiększenie eksportu. Dokonanie przemian strukturalnych w gospodarce jest konieczne do poprawy struktury eksportu i podniesienia poziomu konkurencyjności przedsiębiorstw i gałęzi na rynkach międzynarodowych. Natomiast ta zasadnicza metoda służy poprawie bilansu handlu zagranicznego i zwiększeniu udziału wymiany międzynarodowej w strukturze popytu globalnego.

Za najważniejsza proporcję makroekonomiczną można uznać podział dochodu narodowego na konsumpcję i inwestycje. Oprócz tych dwóch składowych, w strukturze 
popytu globalnego występuje jeszcze eksport netto, który stanowi jeden z przejawów konkurencyjności i innowacyjności gospodarki na rynkach międzynarodowych. Proporcja między konsumpcją a akumulacją decyduje o strukturze spożycia bieżącego i przyszłego. Ważne jest również określenie odpowiedniej proporcji między spożyciem indywidualnym a zbiorowym. Właściwe ukształtowanie konsumpcji indywidualnej i zbiorowej oraz spożycia i akumulacji, a także udziału eksportu netto wpływa na: wydajność pracy, efektywność gospodarowania oraz racjonalność wykorzystania czynników wytwórczych, co ostatecznie oddziałuje na wzrost gospodarczy. W przypadku niektórych krajów zasadniczym problemem wzrostu gospodarczego pozostaje proporcja między popytem wewnętrznym a zewnętrznym. Nie zawsze właściwe jest opieranie wzrostu PKB na popycie zewnętrznym (eksporcie netto) oraz zaniechanie stymulowania popytu wewnętrznego. W niektórych sytuacjach podstawą wzrostu popytu globalnego powinien być większy popyt wewnętrzny, tak aby nie doprowadzić do destabilizacji koniunktury gospodarczej w skali międzynarodowej [Pluciński, 2010, s. 31].

Struktura popytu globalnego jest zagadnieniem coraz bardziej upowszechnianym i dyskutowanym w literaturze ekonomicznej. Wynika to z faktu, że we współczesnych gospodarkach uwidoczniają się istotne przesunięcia w strukturze popytu globalnego między wydatkami konsumpcyjnymi, inwestycyjnymi a eksportem netto. Znaczacy wpływ na ten proces mają zmiany w poziomie rozwoju gospodarczego. Zmiany te są wynikiem innych przemian strukturalnych, jak choćby ograniczania rolnictwa i przemysłu na korzyść usług, czy też silnej reorientacji wewnętrznej w ramach usług, charakteryzującej się spadkiem usług opartych na mniej nowoczesnych rozwiązaniach technologicznych na korzyść usług nowych, które są efektem bardziej wydajnych technologii i postępu w informatyce [Kotlorz, 2005, s. 224-225]. Zasadniczym czynnikiem przemian w strukturze popytu globalnego jest kształtowanie się społeczeństwa informacyjnego. Wywiera to wielopłaszczyznowy wpływ na: funkcjonowanie rynku pracy, popyt na pracę, możliwości funkcjonowania tradycyjnych działów gospodarki oraz zmianę preferencji w odniesieniu do dóbr i usług zaspokajających tradycyjne i nowe potrzeby [Sztanderska, 2002, s. 64].

\section{Metoda badawcza}

W analizie wykorzystano dane roczne (wyrażone w walucie EURO) z bazy EUROSTAT, dotyczące tempa wzrostu gospodarczego oraz struktury popytu globalnego dla dziesięciu krajów Europy Środkowej i Wschodniej (ESW), tj.: Bułgarii, Czech, Estonii, Litwy, Łotwy, Polski, Rumunii, Słowacji, Słowenii i Wegier, za okres 1995-2013. Obliczenia przeprowadzono na podstawie własnych algorytmów wzorów przy pomocy programu Microsoft Office Excel 2007. Dane dotyczące popytu globalnego zestawiono w dwóch układach strukturalnych:

- $\quad$ popyt konsumpcyjny, popyt inwestycyjny, eksport netto (układ trzyelementowy);

- $\quad$ prywatny popyt konsumpcyjny, prywatny popyt inwestycyjny, popyt państwa, eksport netto (układ czteroelementowy). 
W trakcie prowadzenia analizy porównawczej wyżej wspomnianych obiektów (krajów ESW), ze względu na strukturę popytu globalnego, ważnym etapem jest zastosowanie odpowiednich metod normalizacji badanych zmiennych oraz dobór prawidłowych miar podobieństwa struktur [Włodarczyk, 2006, s. 182-183; Włodarczyk, 2011, s. 534-536]. Skoro wszystkie wartości zmiennych opisujących strukturę badanego zjawiska są wyrażone w takich samych jednostkach (w euro), wykorzystano metodę normalizacji, która jest oparta na przekształceniach ilorazowych [Malina, 2004, s. 32-35]. Oznacza to, że dla każdego $j$-tego obiektu (kraju ESW) analizowano strukturę, która jest opisywana ciagiem $m$ wskaźników udziału składowych popytu globalnego $u=\left\{u_{1}, u_{2}, \ldots, u_{m}\right\}$, przy czym są spełnione następujące warunki:

$$
\begin{gathered}
u_{i j t} \in<0,1>, \\
\sum_{i=1}^{m} u_{i j t}=1, \\
\sum_{i=1}^{m} \sum_{j=1}^{r} u_{i j t}=n_{t},
\end{gathered}
$$

gdzie:

$u_{i j t}$ - udział $i$-tego składnika popytu globalnego w całkowitym popycie globalnym w przypadku $j$-tego kraju ESW w $t$-tym roku;

$i$ - składniki popytu globalnego $(i=1,2, \ldots, m)$, gdzie w układzie trzylementowym $m=3$, natomiast w układzie czteroelementowym $m=4$;

$j$ - kraje $\operatorname{ESW}(j=1,2, \ldots, r)$;

$t$ - poszczególne lata $(t=1995,1999, \ldots, 2013)$;

$n_{t}-$ liczba wskaźników struktury $\left(n_{t}=m^{*} r\right)$ dla badanych $r$ obiektów w $t$-tym roku.

Po przeprowadzeniu normalizacji otrzymujemy macierz $U_{i j}^{t}$ o wymiarach $m \times r$, złożoną z $n$ elementów. Macierz ta przyjmuje postać $i$-tego wskaźnika udziału w zbiorze wszystkich $m$ składników rozpatrywanej struktury j-tego obiektu wśród $r$ rozważanych obiektów (krajów ESW) dla t-tego momentu czasu (roku), co można opisać poniższym wzorem:

$$
U_{i j}^{t}=\left[\begin{array}{cccc}
u_{11}^{t} & u_{12}^{t} & \ldots & u_{1 r}^{t} \\
u_{21}^{t} & u_{22}^{t} & \ldots & u_{2 r}^{t} \\
\ldots & \ldots & \ldots & \ldots \\
u_{m 1}^{t} & u_{m 2}^{t} & \ldots & u_{m r}^{t}
\end{array}\right] .
$$

Następnym etapem jest obliczenie miary braku podobieństwa struktury badanego zjawiska gospodarczego między kolejnymi analizowanymi robiektami (krajami ESW) a strukturą wzorcową dla $t$-tego punktu czasowego (roku), [Chomątowski, Sokołowski, 1978, s. 217-219]. Jako strukturę wzorcową przyjęto strukturę popytu globalnego w UE-15 w 2013 roku. Wybór tej struktury jako punktu odniesienia można było uzasadnić integracją krajów Europy Środkowej i Wschodniej z UE-15, a także reali- 
zacją procesu doganiania krajów zachodnich pod względem rozwojowym, a zatem dostosowywaniem struktur popytu globalnego do tych, które są typowe dla UE-15.

Wyliczenie wspomnianych miar braku podobieństwa struktury dla $t$-tego roku między $j$-tym krajem ESW a k-tym obiektem wzorcowym nastąpiło za pomocą wzoru na odległość w przestrzeni euklidesowej $\left(s_{j k}\right)$, [Kukuła, 1996, s. 44-51; Młodak, 2006, s. 46-65]:

$$
s_{j k}=\sqrt{\frac{1}{2} \sum_{i=1}^{m}\left(u_{j i}-u_{k i}\right)^{2}},
$$

gdzie uzyskane wartości wskaźników (5) dla badanych krajów ESW zostały uśrednione dla $t$-tego roku, co pozwoliło ocenić zarówno zakres odchylenia struktury popytu globalnego w krajach ESW od wzorca (UE-15), jak i jej zmiany w czasie. Miara (5) była wystandaryzowana i przyjęła wartości z przedziału $(0,1)$. Im bliższa zero była wartość miary (5), tym struktury były bardziej homogeniczne, natomiast wartość bliższa 1 oznaczała, że badane struktury były w większym stopniu odmienne.

\section{Analiza empiryczna}

\subsection{Wzrost gospodarczy w krajach Europy Środkowej i Wschodniej}

Wzrost gospodarczy w krajach ESW podlegał istotnym zmianom zarówno w ujęciu przestrzennym, jak i czasowym. W badanym okresie można wyróżnić kilka faz trajektorii średniorocznego wzrostu gospodarczego w krajach ESW. Patrząc na ten proces w ujęciu chronologicznym, można zauważyć, że w okresie 1995-2002 był on mocno zróżnicowany i wahał się w przedziale $2 \%-5 \%$ rocznie (rysunek 1 .).

RYSUNEK 1.

Przeciętne tempo wzrostu gospodarczego w Europie Środkowej i Wschodniej w okresie 1995-2013

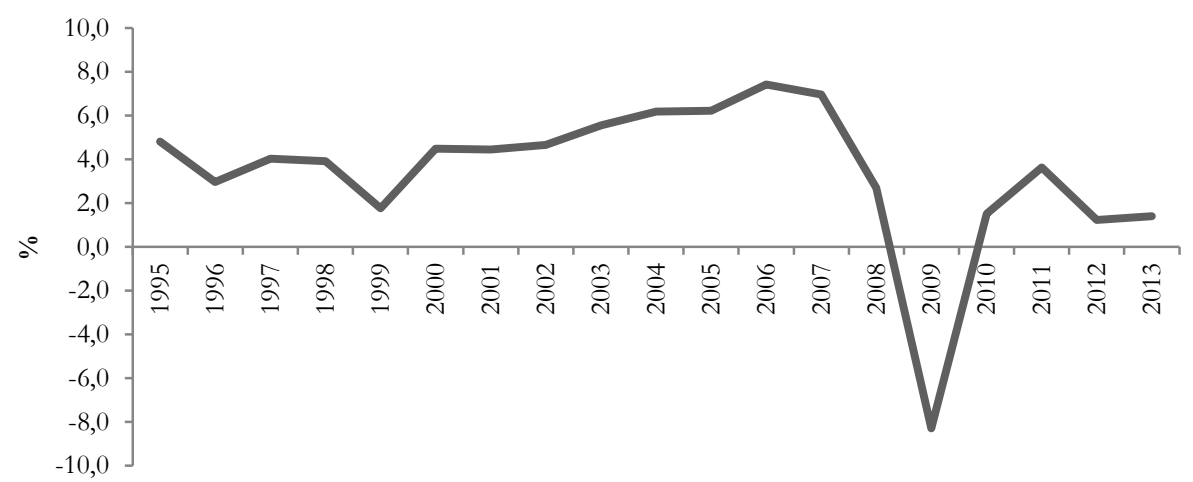

Źródło: opracowanie własne na podstawie danych Eurostat - baza: [Economy and finance...]. 
Z kolei w latach 2003-2007 w regionie pojawiło się mocne przyspieszenie wzrostu gospodarczego, który oscylował w granicach 5\%-7\% rocznie. W następnych latach w krajach ESW, podobnie jak w wielu regionach świata, wystapił silny kryzys gospodarczy, stanowiący konsekwencję zawirowań na światowym rynku finansowym, który urzeczywistnił się potężnym spadkiem realnego PKB, wynoszącym średnio ponad 8\% w 2009 roku. W latach 2010-2013 sytuacja ustabilizowała się, jednak zaobserwowano względnie niskie tempo wzrostu gospodarczego na poziomie około 1\%-3\% rocznie.

Podsumowując, ścieżka czasowa średniego tempa wzrostu gospodarczego w dziesięciu badanych krajach ESW była silnie zróżnicowana. Można dostrzec, że kraje te nie były odporne na zakłócenia na międzynarodowych rynkach finansowych i w najważniejszych gospodarkach świata. Poza tym, warto podkreślić, że kryzys finansowy spowodował to, że średnie tempo wzrostu produkcji finalnej nie powróciło do poziomu notowanego przed 2008 rokiem.

TABELA 1.

Średnioroczne tempo wzrostu gospodarczego i jego zmienność w krajach Europy Środkowej i Wschodniej w latach 1995-2013

\begin{tabular}{|c|c|c|}
\hline Kraj & $\begin{array}{c}\text { Średnioroczne tempo wzrostu } \\
\text { (w \%) }\end{array}$ & $\begin{array}{c}\text { Współczynnik } \\
\text { zmienności (w \%) }\end{array}$ \\
\hline Estonia & 4,7 & 129,0 \\
Litwa & 4,4 & 126,2 \\
Polska & 4,3 & 46,2 \\
Lotwa & 4,1 & 161,9 \\
Słowacja & 4,1 & 83,6 \\
Rumunia & 2,8 & 155,7 \\
Słowenia & 2,8 & 129,6 \\
Czechy & 2,6 & 119,3 \\
Bułgaria & 2,5 & 171,7 \\
Węgry & 1,9 & 145,1 \\
UE-15 & 1,6 & 119,2 \\
\hline
\end{tabular}

Źródło: opracowanie własne na podstawie danych Eurostat - baza: [Economy and finance...].

W tabeli 1. zawarto informacje dotyczące dynamiki wzrostu realnego PKB w poszczególnych krajach ESW. Wykorzystując te dane, można stwierdzić, iż średnioroczny wzrost gospodarczy w latach 1995-2013 zawierał się w przedziale od 1,9\% (Wegry) do 4,7\% (Estonia). Oznacza to dość dużą rozpiętość średniej dynamiki wzrostu realnego PKB wśród krajów ESW, gdyż na przykład Estonia przewyższała w tym względzie Węgry prawie 2,5-krotnie. Wśród badanych państw zwraca uwage pierwsza grupa krajów o relatywnie najszybszej dynamice wzrostu, ze średniorocznym tempem wyższym niż 4\%, tj.: Estonia, Litwa, Polska, Lotwa i Słowacja, oraz druga grupa krajów, których tempo wzrostu było niższe niż 3\% rocznie, tj.: Rumunia, Słowenia, Czechy, Bułgaria i Węgry. Ciekawe wnioski płyną również, gdy w krajach ESW porówna się zmienność tempa wzrostu gospodarczego w czasie. Obliczony współczynnik zmienności wyjaśnia, że najbardziej stabilnego wzrostu gospodarczego doświadczyła Polska (46,2\%), nato- 
miast największe wahania tego wzrostu wystąpiły w Bułgarii (171,7\%), (tabela 1.). Warto także podkreślić, że PKB wszystkich gospodarek badanego regionu wzrastał szybciej niż średnie tempo dla UE-15.

RYSUNEK 2.

Zmienność a tempo wzrostu gospodarczego w Europie Środkowej i Wschodniej w okresie 1995-2013

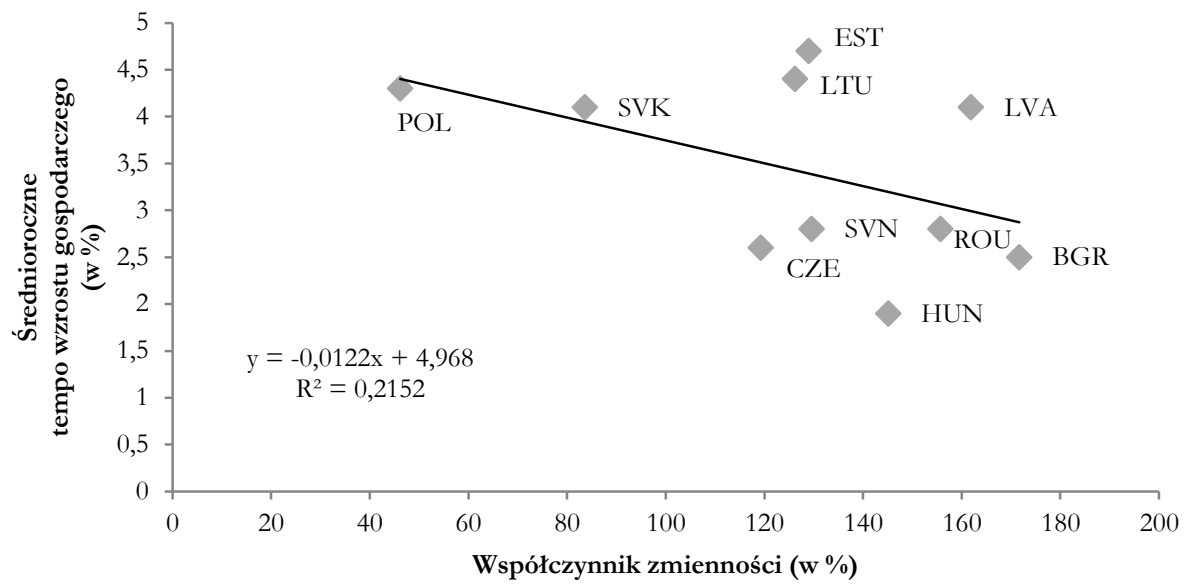

Źródło: jak dla rysunku 1.

RYSUNEK 3.

Zmienność a tempo wzrostu gospodarczego w Europie Środkowej i Wschodniej w okresie 1995-2013 (po wyłączeniu: Litwy, Lotwy i Estonii)

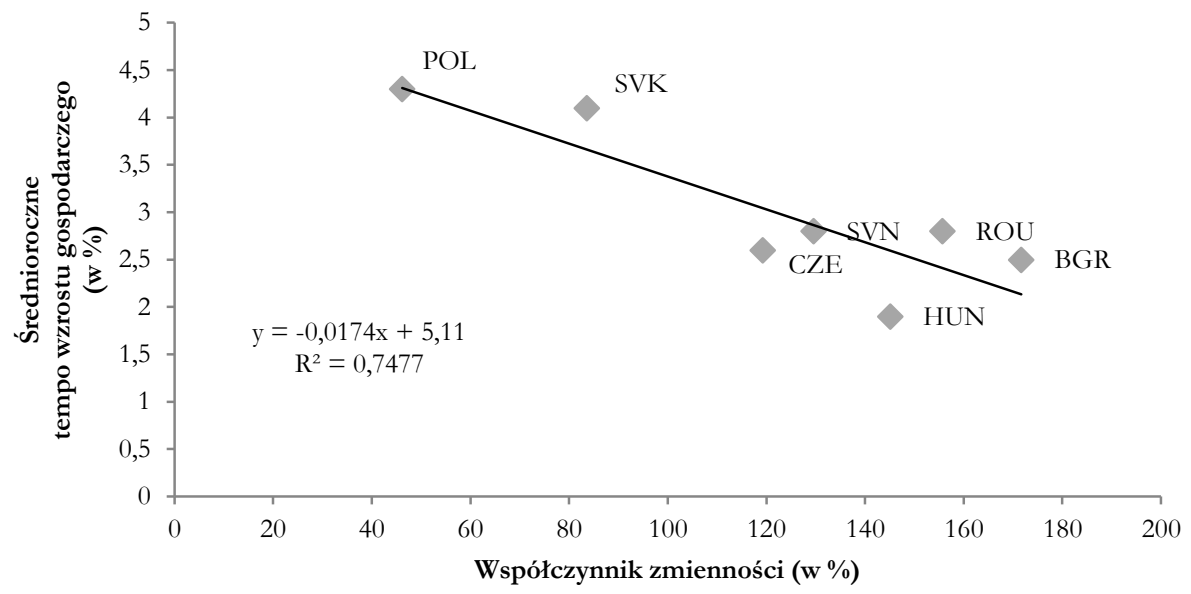

Źródło: jak dla rysunku 1. 
Generalnie ujmując, analizowane kraje ESW, które osiagnęły wyższą średnioroczną dynamikę wzrostu gospodarczego, charakteryzowały się większą stabilnością tego wzrostu (rysunek 2.). Zależność ta była jeszcze bardziej wyraźna po wyłączeniu: Litwy, Łotwy i Estonii (rysunek 3.). Porównanie tempa wzrostu gospodarczego, mierzonego dynamiką realnego PKB, wskazuje, iż poszczególne kraje ESW wyróżniały się różną trajektorią wzrostu. Fakt ten poddaje w wattpliwość kwestię wysokiego stopnia synchronizacji cyklu koniunkturalnego w badanym regionie.

\subsection{Struktura popytu globalnego a wzrost gospodarczy w krajach Europy Środkowej i Wschodniej}

W tabeli 2. została przedstawiona struktura popytu globalnego w 1995 roku dla poszczególnych krajach ESW oraz UE-15. Z danych tych wynika, że w krajach ESW w trzyelementowej strukturze popytu globalnego udział konsumpcji wyniósł średnio $79,6 \%$ i był o 1,4 punktu procentowego wyższy niż przeciętnie w krajach UE-15. Z kolei wydatki inwestycyjne stanowiły $22,2 \%$, co oznacza o ponad 2 punkty procentowe większy udział niż w krajach UE-15. Z powodu słabej wówczas konkurencyjności krajów ESW udział eksportu netto w popycie globalnym był ujemny i niższy o ponad 4 punkty procentowe niż w krajach UE-15.

TABELA 2.

Struktura popytu globalnego w krajach ESW i UE-15 w 1995 roku

\begin{tabular}{|c|c|c|c|c|c|c|c|}
\hline \multirow[b]{2}{*}{ Kraj } & \multicolumn{3}{|c|}{ Układ trzyelementowy } & \multicolumn{4}{|c|}{ Układ czteroelementowy } \\
\hline & konsumpcja & inwestycje & $\begin{array}{l}\text { eksport } \\
\text { netto* }\end{array}$ & $\begin{array}{c}\text { konsumpcja } \\
\text { prywatna }\end{array}$ & $\begin{array}{c}\text { inwestycje } \\
\text { prywatne }\end{array}$ & $\begin{array}{l}\text { wydatki } \\
\text { państwa }\end{array}$ & $\begin{array}{l}\text { eksport } \\
\text { netto* }\end{array}$ \\
\hline Bułgaria & 82,3 & 15,7 & 2,0 & 65,6 & 14,6 & 17,8 & 2,0 \\
\hline Czechy & 71,5 & 32,1 & $-3,6$ & 51,3 & 27,1 & 25,2 & $-3,6$ \\
\hline Estonia & 79,5 & 28,0 & $-7,5$ & 54,1 & 23,0 & 30,4 & $-7,5$ \\
\hline Lotwa & 85,3 & 17,0 & $-2,3$ & 62,7 & 15,1 & 24,5 & $-2,3$ \\
\hline Litwa & 88,0 & 22,6 & $-10,6$ & 63,5 & 19,4 & 27,7 & $-10,6$ \\
\hline Węgry & 77,9 & 21,8 & 0,3 & 54,5 & 21,6 & 23,6 & 0,3 \\
\hline Polska & 79,1 & 18,7 & 2,2 & 60,4 & 15,4 & 22,0 & 2,2 \\
\hline Rumunia & 81,8 & 23,2 & $-5,0$ & 68,7 & 19,1 & 17,2 & $-5,0$ \\
\hline Słowenia & 78,3 & 23,7 & $-2,0$ & 59,8 & 20,5 & 21,7 & $-2,0$ \\
\hline Słowacja & 73,5 & 24,3 & 2,2 & 51,8 & 22,0 & 24,0 & 2,2 \\
\hline $\begin{array}{l}\text { Wartość } \\
\text { średnia }\end{array}$ & 79,6 & 22,2 & $-2,5$ & 59,0 & 19,4 & 23,1 & $-2,5$ \\
\hline UE-15 & 78,2 & 20,1 & 1,7 & 57,8 & 17,0 & 23,5 & 1,7 \\
\hline
\end{tabular}

* Ujemny udział eksportu netto w strukturze popytu globalnego wynika z pojawienia się nadwyżki importu nad eksportem w niektórych krajach.

Źródło: jak w tabeli 1. 
W przypadku czteroelementowej struktury popytu globalnego w 1995 roku udział prywatnych wydatków konsumpcyjnych wyniósł średnio 59,0\% i był wyższy o ponad 1 punkt procentowy niż w krajach UE-15. Prywatne wydatki inwestycyjne stanowiły $19,4 \%$ popytu globalnego i udział ten był wyższy niż w UE-15 o ponad 2 punkty procentowe. Z kolei na publiczne wydatki (konsumpcyjne i inwestycyjne) w krajach ESW przeznaczono przeciętnie $23,1 \%$ popytu globalnego, co było nieznacznie niższym wynikiem niż w krajach UE-15. Udział eksportu netto w popycie globalnym był identyczny, jak w przypadku omawianej już struktury trzyelementowej. W poszczególnych krajach ESW udział wydatków na konsumpcję prywatną zawierał się od 51,3\% (Czechy) do $68,7 \%$ (Rumunia) popytu globalnego. Natomiast prywatne wydatki inwestycyjne oscylowały od 14,6\% (Bułgaria) do 23,0\% (Estonia). Wydatki państwa stanowiły od 17,2\% (Rumunia) do 30,4\% (Estonia). W odniesieniu do eksportu netto udział ten zawierał się od $-10,6 \%$ (Litwa) do 2,2\% (Polska i Słowacja), (tabela 2.). Podsumowując, w 1995 roku rozważane średnie wartości udziałów składowych struktury popytu globalnego w krajach ESW były charakterystyczne dla państw prokonsumpcyjnych, realizujących wzmożone projekty inwestycyjne i jednocześnie mało konkurencyjnych na rynkach międzynarodowych. Średnie wartości udziałów wydatków prywatnych w tworzeniu popytu globalnego w krajach ESW były wyższe niż w UE-15, co wynikało z dynamicznie rozwijającego się ówcześnie sektora prywatnego. Jednak trzeba podkreślić, że w przypadku poszczególnych krajów ESW występowały bardzo silne różnice w kształcie struktury popytu globalnego. Generalnie w krajach ESW uwidocznił się wysoki udział popytu wewnętrznego, zaś mniejsze było znaczenie popytu zewnętrznego.

TABELA 3.

Struktura popytu globalnego w krajach ESW i UE-15 w 2013 roku

\begin{tabular}{|c|c|c|c|c|c|c|c|}
\hline \multirow{2}{*}{ Kraj } & \multicolumn{3}{|c|}{ Układ trzyelementowy } & \multicolumn{4}{c|}{ Układ czteroelementowy } \\
\cline { 2 - 8 } & $\begin{array}{c}\text { konsum- } \\
\text { pcja }\end{array}$ & inwestycje & $\begin{array}{c}\text { eksport } \\
\text { netto }\end{array}$ & $\begin{array}{c}\text { konsumpcja } \\
\text { prywatna }\end{array}$ & $\begin{array}{c}\text { inwestycje } \\
\text { prywatne }\end{array}$ & $\begin{array}{c}\text { wydatki } \\
\text { państwa }\end{array}$ & $\begin{array}{c}\text { eksport } \\
\text { netto }\end{array}$ \\
\hline Bułgaria & 80,0 & 20,9 & $-0,9$ & 63,0 & 16,8 & 21,1 & $-0,9$ \\
Czechy & 71,4 & 22,3 & 6,3 & 50,7 & 19,5 & 23,5 & 6,3 \\
Estonia & 72,1 & 27,1 & 0,8 & 52,5 & 22,7 & 24,0 & 0,8 \\
Lotwa & 79,0 & 22,9 & $-1,9$ & 62,5 & 19,0 & 20,4 & $-1,9$ \\
Litwa & 80,6 & 18,5 & 0,9 & 63,7 & 15,1 & 20,3 & 0,9 \\
Węgry & 74,4 & 17,6 & 8,0 & 53,9 & 13,7 & 24,4 & 8,0 \\
Polska & 78,9 & 18,7 & 2,4 & 60,8 & 14,9 & 21,9 & 2,4 \\
Rumunia & 77,6 & 22,9 & $-0,5$ & 62,8 & 18,4 & 19,3 & $-0,5$ \\
Słowenia & 76,2 & 17,1 & 6,7 & 56,0 & 13,4 & 23,9 & 6,7 \\
Słowacja & 75,4 & 18,3 & 6,3 & 57,6 & 16,2 & 19,9 & 6,3 \\
Wartość & 76,5 & 20,4 & 2,8 & 58,2 & 16,8 & 21,8 & 2,8 \\
średnia & 76,5 & & & & & \\
UE-15 & 80,0 & 17,2 & 2,8 & 58,2 & 15,1 & 24,0 & 2,8 \\
\hline
\end{tabular}

Źródło: jak w tabeli 1. 
W tabeli 3. została przedstawiona struktura popytu globalnego w 2013 roku dla poszczególnych krajów ESW oraz UE-15. Z danych tych wynika, że w trzyelementowej strukturze popytu globalnego udział konsumpcji wyniósł średnio $76,5 \%$ i był o 3,5 punktu procentowego niższy niż przeciętnie w krajach UE-15. Z kolei wydatki inwestycyjne równały się $20,4 \%$, co stanowiło o ponad 3 punkty procentowe większy udział niż w krajach UE-15. Udział eksportu netto w popycie globalnym był identyczny w krajach ESW i UE-15, obejmując przeciętnie 2,8\% popytu globalnego.

W przypadku czteroelementowej struktury popytu globalnego udział prywatnych wydatków konsumpcyjnych wyniósł średnio $58,2 \%$ i był identyczny, jak w krajach UE-15. Z kolei prywatne wydatki inwestycyjne stanowiły 16,8\%, co oznacza wyższy udział o blisko 2 punkty procentowe niż w krajach UE-15. Publiczne wydatki konsumpcyjne $\mathrm{i}$ inwestycyjne w krajach ESW równały się przeciętnie 21,8\% popytu globalnego, co było o ponad 2 punkty procentowe niższe niż w krajach UE-15. Udział eksportu netto w popycie globalnym w krajach ESW był identyczny, jak w UE-15. W poszczególnych krajach ESW udział wydatków na konsumpcję prywatną zawierał się od 50,7\% (Czechy) do 63,7\% (Litwa). Natomiast prywatne wydatki inwestycyjne oscylowały od 13,4\% (Słowenia) do 22,7\% (Estonia), a wydatki państwa - od 19,3\% (Rumunia) do $24,4 \%$ (Węgry). W odniesieniu do eksportu netto udział ten zawierał się od 1,9\% (Lotwa) do 8,0\% (Wegry). Podsumowując, w latach 1995-2013 nastapił w krajach ESW z jednej strony wzrost udziału eksportu netto, z drugiej - silny spadek udziału konsumpcji i inwestycji. Świadczy to o tym, że zwiększyła się rola popytu zewnętrznego, lecz istotnie zmalał popyt wewnętrzny, a w szczególności popyt konsumpcyjny. Zaobserwowana wyraźna poprawa udziału eksportu netto, która zaowocowała zrównaniem się wartości tego wskaźnika struktury z UE-15, wynikała z podniesienia jakości produktów oraz poprawy konkurencyjności gospodarek badanego regionu na rynkach międzynarodowych. Tymczasem, patrząc na rozbieżności między poszczególnymi krajami ESW, to w latach 1995-2013 zmnieszyły się różnice w udziałach trzech składowych popytu globalnego: wydatków państwa, konsumpcji prywatnej i eksportu netto, następnie nieznacznie zwiększyły się rozbieżności w zakresie udziału popytu inwestycyjnego.

Na rysunku 4. zaprezentowano odległość poszczególnych struktur popytu globalnego w krajach ESW od analogicznych struktur w UE-15. Z wyników przedstawionych graficznie można wywnioskować, że zarówno trzy-, jak i czteroelementowa struktura popytu globalnego były w zbliżonym stopniu oddalone od analogicznych struktur w UE-15. Jednak uwzględniając ujęcie dynamiczne, można zauważyć, że w latach 1995-2007 wskaźnik odległości euklidesowej wzrastał, co dowodzi, że struktury popytu globalnego w ESW oddalały się od analogicznych struktur w UE-15. Wyraźny spadek wskaźnika odległości euklidesowej zaobserwowano od 2008 roku, co należy łączyć z wybuchem kryzysu na światowym rynku finansowym. Wiaże się to z tym, że w latach 2008-2013 struktury popytu globalnego w krajach ESW zaczęły systematycznie zbliżać się do analogicznych struktur w UE-15. 
RYSUNEK 4.

Średnia odległość euklidesowa struktury popytu globalnego w układzie trzyelementowym (MP3) i czteroelementowym (MP4) w krajach Europy Środkowej i Wschodniej na tle analogicznej struktury w krajach UE-15

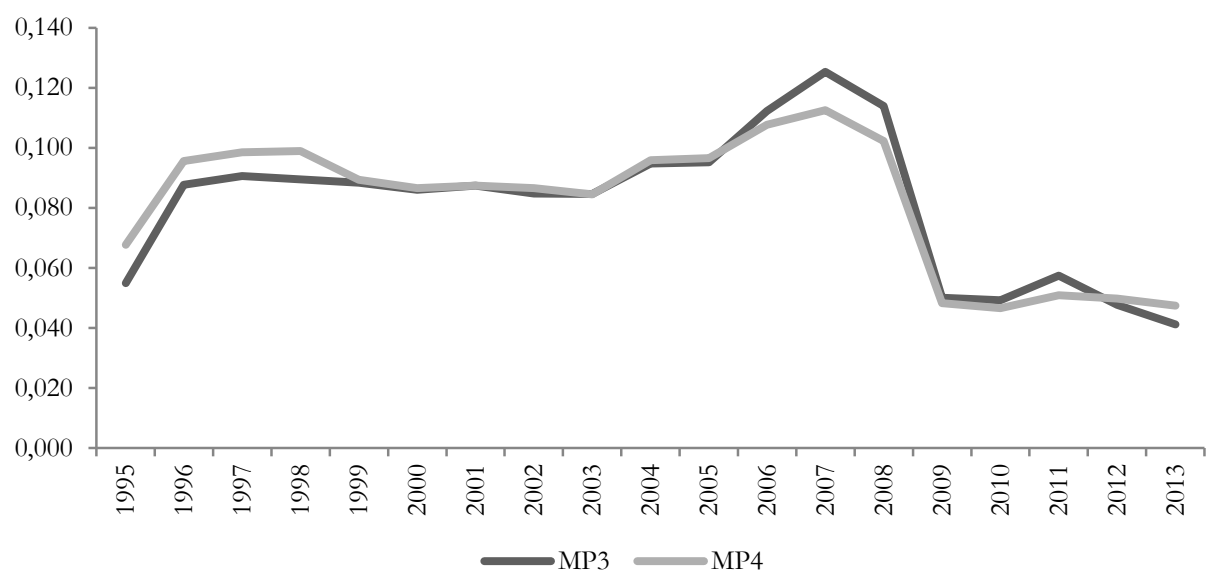

Źródło: jak dla rysunku 1.

TABELA 4.

Odległość euklidesowa struktury popytu globalnego w krajach ESW w latach 1995-2013 na tle UE-15

\begin{tabular}{|c|c|c|c|c|c|c|}
\hline Kraj & $\begin{array}{c}\text { Średnia } \\
\text { wartość } \\
\text { MP3 } \\
\text { w latach } \\
\text { 1995-2013 }\end{array}$ & $\begin{array}{c}\text { Zmiana }^{\mathrm{a}} \\
\text { MP3 } \\
\text { w latach } \\
1995-2013\end{array}$ & $\begin{array}{c}\text { Wartość } \\
\text { MP3 } \\
\text { w } 2013 \\
\text { roku }\end{array}$ & $\begin{array}{c}\text { Średnia war- } \\
\text { tość MP4 } \\
\text { w latach 1995- } \\
2013\end{array}$ & $\begin{array}{c}Z_{\text {Zmiana }}{ }^{\text {MP4 }} \\
\text { w latach } \\
1995-2013\end{array}$ & $\begin{array}{c}\text { Wartość } \\
\text { MP3 } \\
\text { w } 2013 \\
\text { roku }\end{array}$ \\
\hline Bułgaria & 0,079 & 0,018 & 0,037 & 0,105 & $-0,019$ & 0,050 \\
\hline Czechy & 0,099 & $-0,054$ & 0,076 & 0,085 & $-0,041$ & 0,067 \\
\hline Estonia & 0,110 & $-0,015$ & 0,091 & 0,095 & $-0,038$ & 0,069 \\
\hline Lotwa & 0,099 & 0,001 & 0,052 & 0,101 & 0,010 & 0,058 \\
\hline Litwa & 0,077 & $-0,101$ & 0,016 & 0,086 & $-0,061$ & 0,049 \\
\hline Węgry & 0,059 & 0,015 & 0,055 & 0,056 & $-0,007$ & 0,049 \\
\hline Polska & 0,044 & 0,001 & 0,014 & 0,051 & 0,002 & 0,024 \\
\hline Rumunia & 0,091 & $-0,021$ & 0,050 & 0,109 & $-0,051$ & 0,057 \\
\hline Słowenia & 0,063 & $-0,019$ & 0,039 & 0,050 & $-0,021$ & 0,034 \\
\hline Slowacja & 0,080 & $-0,027$ & 0,042 & 0,076 & $-0,027$ & 0,040 \\
\hline
\end{tabular}

a - Zmiana odległości euklidesowej struktury popytu globalnego w poszczególnych krajach ESW w 2013 roku w porównaniu z 1995 rokiem.

Źródło: jak w tabeli 1. 
Wartość wskaźnika odległości euklidesowej była istotnie zróżnicowana między krajami ESW (tabela 4.). W przypadku trzyelementowej struktury popytu globalnego średnia odległość euklidesowa w latach 1995-2013 zawierała się od 0,044 (Polska) do 0,110 (Estonia). Zatem trzyelementowa struktura polskiego popytu globalnego była najbardziej podobna, a estońskiego - najbardziej zróżnicowana w porównaniu z UE-15. W latach 1995-2013 najsilniejsze upodobnienie się badanej struktury do krajów UE-15 zaobserwowano na Litwie $(-0,101)$. Z kolei w Bułgarii zanotowano największe oddalenie się badanej struktury od UE-15 (0,018). W 2013 roku najbardziej od krajów UE-15 różniła się struktura estońskiego popytu globalnego, natomiast najmniej - struktura polskiego popytu globalnego. Z kolei dla czteroelementowej struktury popytu globalnego średnia odległość euklidesowa w latach 1995-2013 zawierała się od 0,050 (Słowenia) do 0,109 (Rumunia). Oznacza to, że czteroelementowa struktura słoweńskiego popytu globalnego była najbardziej podobna, a rumuńskiego - najbardziej zróżnicowana w porównaniu z krajami UE-15. W latach 1995-2013 największe upodobnienie się badanej struktury do krajów UE-15 stwierdzono na Litwie $(-0,061)$. Tymczasem na Lotwie wystapiło w badanym okresie oddalenie się struktury popytu globalnego od UE-15 $(0,010)$. W 2013 roku najbardziej od krajów UE-15 różniła się struktura estońskiego popytu globalnego, a najmniej - struktura polskiego popytu globalnego.

\section{Tempo wzrostu gospodarczego* a odległość euklidesowa (MP3) struktury popytu globalnego** między krajami ESW a UE-15}

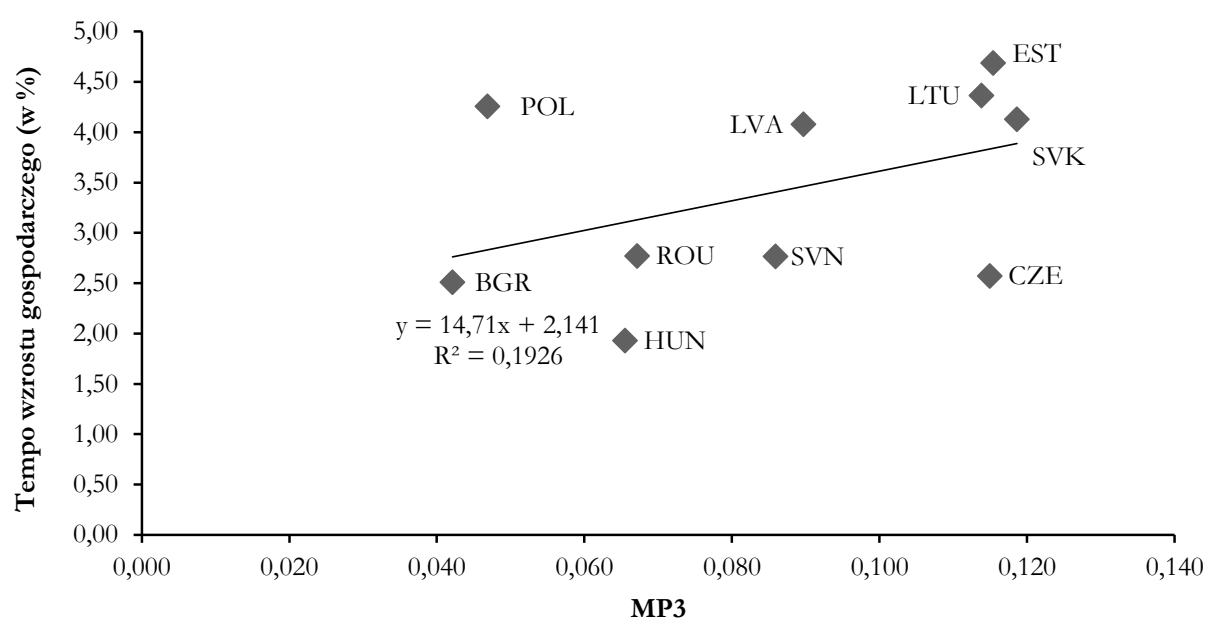

\footnotetext{
* średnioroczne tempo w latach 1995-2013

** średnia wartość w latach 1995-1999

Źródło: jak dla rysunku 1.
} 


\section{Tempo wzrostu gospodarczego* a odległość euklidesowa (MP4) struktury popytu globalnego** między krajami ESW a UE-15}

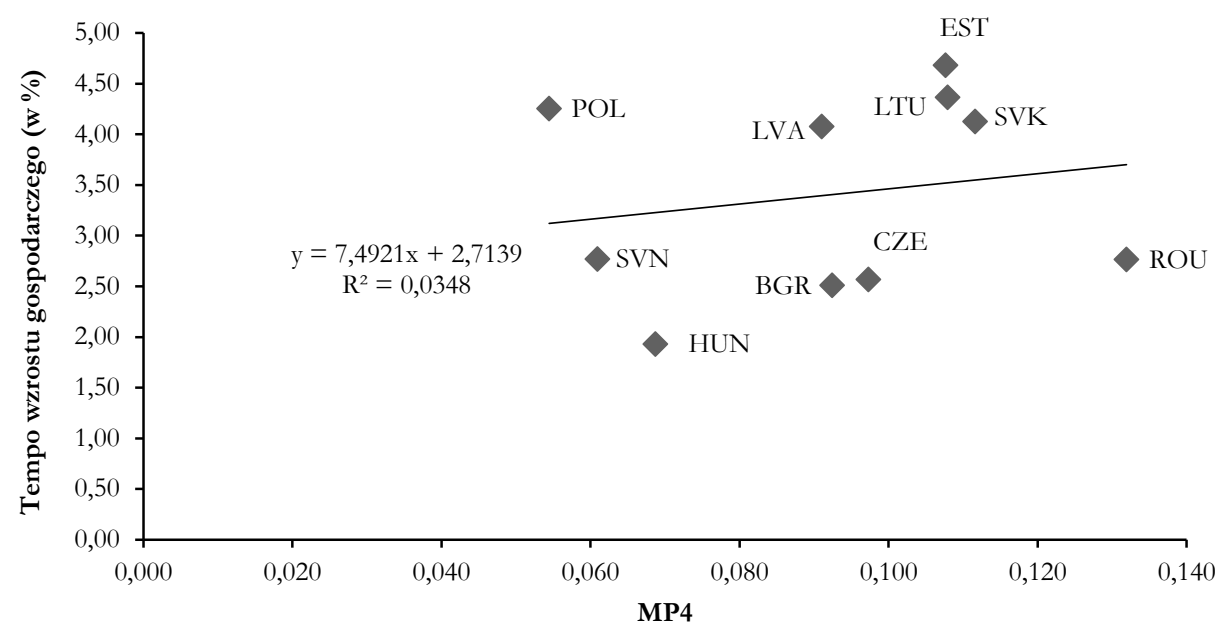

* średnioroczne tempo w latach 1995-2013

** średnia wartość w latach 1995-1999

Źródło: jak dla rysunku 1.

Na rysunkach: 5. i 6. przedstawiono zależność między wyliczoną odległością euklidesowa - dla struktur popytu globalnego między krajami ESW i UE-15 w latach 1995-1999 - a osiagniętym średniorocznym tempem wzrostu gospodarczego przez kraje ESW w latach 1995-2013. Wynika z tego, że między tymi kategoriami pojawia się dodatnia zależność, tzn. kraje ESW, które miały większą odległość euklidesową struktur popytu globalnego od struktur UE-15, osiąały wyższe średnioroczne tempo wzrostu gospodarczego. Jednak trzeba podkreślić, że ta zależność nie jest spełniona dla wszystkich badanych krajów i choć wydaje się silniejsza dla trzyelementowej struktury popytu globalnego, to nadal dopasowanie zmiennych jest niskie, a zatem wszelkie wnioskowanie w tej kwestii musi zachodzić z dużą ostrożnością.

\section{Podsumowanie}

Przeprowadzone w artykule analizy pozwoliły sformułować kilka końcowych wniosków.

Po pierwsze, przemiany strukturalne w gospodarce umożliwiają zwiększenie międzynarodowej konkurencyjności gospodarki i wzrost eksportu. Poprawa bilansu handlowego i zwiększenie udziału wymiany międzynarodowej w strukturze popytu globalnego stanowią ważny element wzrostu gospodarczego i podniesienia dobrobytu. Trzeba także 
pamiętać, że dynamizowanie popytu globalnego nie może odbywać się wyłącznie na bazie stymulacji popytu zewnętrznego, bowiem kluczowym czynnikiem rozwoju jest pobudzenie również popytu wewnętrznego.

Po drugie, w warunkach stabilnego otoczenia gospodarczego kraje ESW rozwijały się w zróżnicowanym tempie, czego dowodem był średnioroczny wzrost realnego PKB na poziomie $2-7 \%$. Jednocześnie można zauważyć, że koniunktura makroekonomiczna w tych krajach była szczególnie wrażliwa na zakłócenia w światowym systemie finansowym i gospodarkach wyżej rozwiniętych.

Po trzecie, porównując strukturę popytu globalnego badanych krajów ESW z UE-15 można zauważyć, że w przypadku tych pierwszych krajów niższy był udział konsumpcji, natomiast wyższy - udział inwestycji. Z kolei średni udział eksportu netto w strukturze popytu globalnego analizowanych dziesięciu krajów ESW był identyczny, jak w przypadku krajów UE-15. W latach 1995-2013 zaszły diametralne zmiany w strukturze popytu globalnego. Widoczne było osłabienie popytu wewnętrznego, a zwłaszcza popytu konsumpcyjnego, oraz silne zwiększenie popytu zewnętrznego.

Po czwarte, struktury popytu globalnego w krajach ESW oddalały się w latach 1995-2007, zaś po wybuchu kryzysu na rynkach finansowych struktury te wykazywały tendencję do upodabniania się do analogicznych struktur w UE-15.

Po piąte, zależność między stopniem zróżnicowania struktury popytu globalnego krajów ESW i UE-15 a tempem wzrostu gospodarczego wydaje się dodatnia, jednakże dopasowanie zmiennych było słabe i nieistotne statystycznie. Względnie najsilniejszy związek, choć nadal nieistotny statystycznie, zaobserwowano dla trzyelementowej struktury popytu globalnego. Powód ujawnia fakt, że kraje ESW wciąż charakteryzują się bardzo zróżnicowanymi strukturami popytu globalnego, co w efekcie oznacza zarazem odmienne tempo wzrostu gospodarczego.

\section{Literatura}

Broszkiewicz R. 2004 Uwarunkowania i skutki polityki zmian strukturalnych w gospodarce polskiej w okresie transformacji, [w:] Przemiany strukturalne polskiej gospodarki wobec wyzwan integracyjnych ₹ Unia Europejska, Z. Mikołajewicz (red.), Wydawnictwo Uniwersytetu Opolskiego, Opole.

Bywalec C. 2007 Konsumpcja w teorii i praktyce gospodarowania, Wydawnictwo Naukowe PWN, Warszawa.

Chomątowski S., Sokołowski A. 1978 Taksonomia struktur, „Przegląd Statystyczny”, nr 2.

Economy and finance/National Accounts, dokument elektroniczny, tryb dostępu: [http:// ec.europa.eu/Eurostat, data wejścia: 22.04.2014].

Jędruchniewicz A. 2011 Struktura popytu globalnego w Polsce, „Research Papers of Wrocław University of Economics", no. 168.

Kaczorowski P., Rogut A., Tokarski T. 2002 C:y sektorowe zmiany strukturalne w Polsce maja charakter posytywnego szoku podażowego?, [w:] Wrrost gospodarçy, restrukturyzacja $i$ bezrobocie w Polsce. Ujecie teoretyczne $i$ empiryczne, S. Krajewski, T. Tokarski (red.), Wydawnictwo Uniwersytetu Lódzkiego, Lódź. 
Karpiński A. 1986 Restrukturyzacja gospodarki w Polsce i na śmiecie, PWE, Warszawa.

Keynes J.M. 1985 Ogólna teoria zatrudnienia, procentu i pieniqdza, Wydawnictwo Naukowe PWN, Warszawa.

Kotlorz D. 2005 Zmiany w diriałowej strukturze zatrudnienia w Polsce w latach 1995-2001, [w:] Wrost gospodarczy, restrukturyzacja i rynek pracy w Polsce. Ujecie teoretyczne $i$ empiryczne, S. Krajewski, L. Kucharski (red.), Wydawnictwo Uniwersytetu Lódzkiego, Łódź.

Kukuła K. 1996 Statystyczne metody analizy struktur ekonomicznych, Wydawnictwo Edukacyjne, Kraków.

Malina A. 2004 Wielowymiarowa analiza pržestræennego zróżnicowania struktury gospodarki Polski wedtug województw, Wydawnictwo Akademii Ekonomicznej w Krakowie, Kraków.

Młodak A. 2006 Analiza taksonomiczna w statystyce regionalnej, Wydawnictwo Difin, Warszawa.

Pluciński E. 2010 Mięzy wolnym handlem a protekcjonizmem gospodarçym. Depresja 1933 versus kryzys 2009, [w:] Mięzy kryzysem a wspótpraca gospodarczq: prayketady wyzwań i problemów w stosunkach międzynarodowych końca piernszej dekady XXI wiek.u, M. Lasoń (red.), Wydawnictwo Krakowskiej Akademii im. Andrzeja Frycza Modrzewskiego, Kraków.

Sadowski Z. 2005 Transformacja i rozwój. Wybór prac, PTE, Warszawa.

Sosenko K. 2008 Problemy filozofii $i$ metodologii nank dla ekonomistów, Wydawnictwo Uniwersytetu Ekonomicznego w Krakowie, Kraków.

Straub R., Tchakarov I. 2007 Assessing the impact of a change in the composition of public spending. A DSGE approach, „European Central Bank Working Paper Series”, no. 795, August.

Sztanderska U. 2002 Zmiany w strukturze zawodów, [w:] Polska w drodze do globalnego spoteczeństwa informacyjnego. Raport o rozwoju spotecznym, W. Cellary (red.), UNDP Poland, Warszawa.

Włodarczyk R.W. 2006 Delimitacja zmian struktury produkecji sprzedanej przedsiębiorstw w przetwórstiwe przemyslowym - aspekt makroekonomiczny, [w:] Nowoczesne metody i techniki w zarzqdzaniu, J. Duda, W. Waszkielewicz (red.), Uczelniane Wydawnictwa NaukowoTechniczne, AGH, Kraków.

Włodarczyk R.W. 2011 Zróżnicowanie sektorowej struktury pracujacych w strefie euro, „Ekonomista", nr 4.

Woźniak M.G. 2004 W zrost gospodarczy. Podstawy teoretyczne, Wydawnictwo Akademii Ekonomicznej w Krakowie, Kraków.

Wydymus S. 1988 Analiza porównawcza struktur gospodarczych, [w:] Metody statystyki miedżynarodowej, A. Zeliaś (red.), PWE, Warszawa. 